COMUNICACIÓN/COMMUNICATION

\title{
DEL BOCETO AL DISEÑO. LA MATERIALIZACIÓN DEL DISCURSO VISUAL EN EL DISEÑO GRÁFICO
}

Roberto Gamonal Arroyo1: Universidad Complutense de Madrid. España robertogamonal@yahoo.es

\section{RESUMEN}

¿Cómo se transforma una idea en un diseño? Esa ha sido siempre una pregunta que se han hecho muchos investigadores en una disciplina difícil de clasificar como es el Diseño Gráfico. Desde este artículo intentaremos aportar una nueva visión, pero partiendo de una materia con muchos siglos de historia: la Retórica. Veremos cómo la manera de elaborar una idea para utilizar en un discurso retórico se puede trasladar al Diseño Gráfico. Y es que todo diseño nace de las palabras como sustancia expresiva de las ideas para transformarse en imágenes como resultado de la materialización de un pensamiento previo que sufre unas alteraciones en su modo de expresión para resultar más atractivo y cumplir su objetivo comunicativo. Nos valdremos para explicar este complejo proceso del análisis de algunos de los trabajos del diseñador gráfico Manuel Estrada, uno de los principales exponentes del Diseño español. A través de sus bocetos podremos ver el camino recorrido desde la idea hasta el resultado final.

PALABRAS CLAVE: Diseño Gráfico - Comunicación Visual - Creatividad - Proceso del Diseño - Discurso del Diseño

\footnotetext{
${ }^{1}$ Autor correspondiente:

Roberto Gamonal Arroyo: Profesor Asociado de la Facultad de Ciencias de la Información en la Universidad Complutense de Madrid, España

Correo: robertogamonal@yahoo.es
} 


\title{
FROM THE SKETCH TO THE DESIGN. THE MATERIALIZATION OF VISUAL DISCOURSE IN THE GRAPHIC DESIGN
}

\begin{abstract}
How does idea transform in a design? This it has been always a question that many investigators have done to themselves in a discipline difficult to classify like the Graphic Design. From this article we will try to contribute a new vision, but departing from a discipline with many centuries of history: the Rhetoric. We will see how the way of elaborating an idea to use in a rhetorical speech can move to the Graphic Design. All design is born from the words as expressive substance of the ideas to transform in images as result of the materialization of a previous thought that suffers a few alterations in his way of expression to turn out to be more attractive and to fulfill his communicative aim. We will use to explain this complex process of the analysis of some of the works of the graphic designer Manuel Estrada, one of the principal exponents of the Spanish Design. By his sketches we will be able to see the way crossed from the idea up to the final result.
\end{abstract}

KEY WORDS: Graphic Design - Visual Communication - Creativity - Design Process - Design Discourse

\section{INTRODUCCIÓN}

La gestación de la ideas siempre ha estado rodeada de un mito romántico. Sobre todo en el terreno del Arte. Y por una confusión generalizada, este prejuicio también se ha trasladado al Diseño Gráfico por su innegable influencia artística y por su plasmación plástica y figurativa a través de la imagen. Pero el Diseño Gráfico, más que una forma de autoexpresión del autor, responde a la necesidad de solucionar un problema de índole comunicativa que tiene un cliente particular o una compañía en el que el diseñador cumple una función de mediador entre quien realiza un encargo y el público al que va dirigido el mensaje que ha creado con elementos propios del lenguaje visual con el objetivo de convencer y persuadir.

Desde esta perspectiva, el diseñador gráfico escribe un discurso utilizando signos visuales, traduce la palabra en imagen, con la intención de modificar una actitud en el receptor del mensaje: comprar un producto, utilizar un servicio, identificar una empresa, votar a un candidato, acudir a un evento, informar de un hecho, etc. Todas estas acciones tienen un punto en común: la persuasión a través del discurso.

Y esto ya ha sido estudiado por la Retórica desde el siglo V a. C. Por tanto, un orador clásico guarda mucha similitud con un diseñador gráfico del siglo XXI. Veamos los puntos en común de estas dos disciplinas que nos ocupan. 


\section{PUNTOS EN COMÚN ENTRE LA RETÓRICA Y EL DISEÑO GRÁFICO}

La Retórica es considerada por los griegos como $\tau \varepsilon \chi v \eta$ y por los romanos como ars (Lausberg, 1983, pp. 59-70). Con estos términos se intenta designar un proceso ejecutado conforme a un plan y realizado por un ser racional en contraposición a los

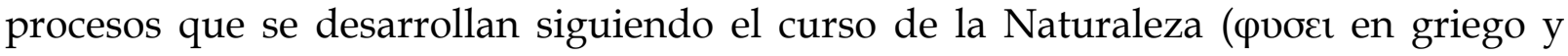
natura en latín) o bien son producto del azar (toxๆ en griego y casu en latín). Técnica y Arte en la cultura clásica son sinónimos.

Para los griegos y los romanos, un escultor no era un artista en el sentido que conocemos actualmente, sino una persona con conocimientos técnicos y con dominio de los materiales y los procesos necesarios para llevar a cabo una obra (epyov en griego y opus en latín) que previamente había sido planificada, es decir, que no había sido fruto ni del azar ni de la Naturaleza. Estos artistas no daban rienda suelta a su ingenio, sino que se ajustaban a los preceptos, cánones y modos de proceder instituidos en su disciplina. La valoración de su obra se realizaba en función del dominio de la técnica y el ajuste a los cánones de belleza clásica. Si no lo hacían, su trabajo no era considerado "bueno", en el sentido helénico del término, es decir, bueno, bello y útil a la vez.

Siguiendo a Lausberg, podemos determinar que el Diseño es un techné que está dentro del género poético ya que su resultado es una obra artificial (opus) que se muestra terminada (ars in effectu posita), que ha sido previamente planificada por un diseñador (artifex) y que está destinada al uso (usus). Por lo tanto, desde un punto de vista clásico, podríamos decir que el Diseño es una técnica y el diseñador es un "poeta".

Veamos una serie de relaciones que mantienen la Retórica y el Diseño Gráfico que nos permiten afirmar que ambas disciplinas tienen mucho que ver la una con la otra:

\section{- Connotación peyorativa}

La Retórica ha sido considerada durante mucho tiempo como un mero catálogo de figuras retóricas dando lugar a una definición negativa de lenguaje artificioso, banal y ampuloso. El Diseño Gráfico también ha sufrido un cierto desprecio debido a prácticas incorrectas por parte de algunos diseñadores cuyos productos diseñados se basan más en la forma que en la función. Su íntima relación con la Publicidad le ha llevado también a ser relacionado con el consumismo.

\section{- Cotidianeidad}

La Retórica aparece constantemente en nuestro lenguaje de cada día. Según Lakoff y Johnson (1991), utilizamos constantemente figuras retóricas, muchas veces sin advertirlo, ya que se han instalado de forma convencional en nuestras expresiones cotidianas. Sobre todo la metáfora, que estructura nuestras acciones y formas de pensar. Desde sus orígenes griegos, se utilizó en el ámbito jurídico y político para defender o acusar buscando la adhesión del jurado y la asamblea respectivamente. Después evolucionó hacia una aplicación literaria y poética y se instaló también en el sistema educativo. El campo de las artes también se ha visto influido por la Retórica en 
diferentes disciplinas como la Arquitectura, la Pintura o la Música.

En la Comunicación contemporánea se dejan notar las bases de la Retórica. Es clara su presencia en la Publicidad actual y se habla también de una Retórica de la Imagen en la que tendría cabida el Diseño Gráfico como generador de piezas gráficas para la Comunicación Visual. Pero su red se ha extendido a otros campos más dispares.

En cuanto al Diseño, podemos decir que estamos constantemente bombardeados por imágenes, por mensajes gráficos que pueblan nuestro paisaje urbano. Son piezas de Diseño Gráfico que están presentes en nuestra vida cotidiana como el periódico que leemos todas las mañanas, el libro de texto que estudiamos para preparar un examen, el calendario que consultamos para ver qué día es, el mapa del metro para elegir la ruta más rápida, la caja del detergente que usamos para lavar la ropa, la etiqueta de la botella de vino que compartimos con los amigos, el brick de leche que tomamos para desayunar, los carteles que vemos paseando, las vallas publicitarias que contemplamos por las carreteras desde nuestro automóvil, el manual de instrucciones para instalar cualquier aparato electrónico, la invitación que nos mandan para acudir a un evento, las carátulas de los CD de música... La lista sería interminable y en todos ellos ha participado un diseñador gráfico.

\section{- Conceptos ambiguos o mal entendidos}

Tras unos orígenes esplendorosos, la Retórica cayó en el más profundo olvido y sólo se tenía en cuenta una parte de su proceso de creación del discurso: la elocutio, obviando la inventio y la dispositio. Será a partir de la publicación del “Tratado de la Argumentación" de Perelman y Olbrechts-Tyteca (1989) cuando la Retórica resucite con toda la fuerza persuasiva que había sido concebida por Aristóteles a través de los argumentos y confiriéndole un carácter racional que le había sido arrebatado durante siglos.

Por su lado, las piezas gráficas o diseños siempre han sido vistos como el producto de la intuición del diseñador, sin tener en cuenta que son fruto de un proceso de trabajo. Quizá porque el público sólo ha visto el producto finalizado y no ha tenido acceso a su proceso de proyectación. Como hemos comentado, la mayoría de las publicaciones de Diseño Gráfico nos muestran excelentes trabajos en forma de anuarios, pero no incluyen una explicación de cómo se ha llegado hasta ahí.

La irrupción de los ordenadores en el campo del Diseño Gráfico ha supuesto una falsa idea de la "democratización" de esta disciplina, llegándose a pensar que cualquier persona que tuviera una computadora podría ejercer de diseñador gráfico de una manera profesional.

\section{- Carácter procesual y proyectivo}

Las dos disciplinas nos proporcionan productos que son fruto de un proceso de trabajo. Los dos tienen un carácter intrínsecamente proyectivo ya que mediante sus procesos se va configurando el producto antes de que esté finalizado.

En el caso de la Retórica el producto es el discurso hablado o escrito. El producto del 
Diseño Gráfico es la pieza gráfica o diseño, al que también podríamos denominar discurso visual. Los dos productos se obtienen mediante procesos racionalmente intencionados que no dejan nada al azar.

\section{- Carácter creativo y constructivo}

La Creatividad es un nexo de unión entre Retórica y Diseño Gráfico. Ambos son actividades creativas. Esta apreciación no aparece explícitamente en la mayoría de las definiciones sobre Retórica, pero sí implícitamente en la definición que hace el Grupo $\mu$. Para este grupo de investigadores, la Retórica es un conjunto de desviaciones que modifican el lenguaje infringiendo normas sintácticas y semánticas e inventando otras nuevas. Este carácter rupturista, de alejamiento de las reglas es una cualidad distintiva de la Creatividad.

\section{- Uso publicitario}

Son materias que debe tener muy presente el publicitario ya que intervienen en su proceso de creación.

El resurgir de la Retórica a mediados del siglo XX también tuvo mucho que ver con su uso en el ámbito publicitario. En un principio se centraba en los textos o copy, siendo una herramienta excelente para la creación de eslóganes, pero como estamos viendo, también tiene aplicación en la imagen publicitaria que ya vislumbraron en sus estudios Roland Barthes (1986) y Jacques Durand (1972).

Todo lo relacionado con la imagen estática es tarea del Diseño Gráfico Publicitario. Los anuncios en publicaciones y carteles como estrategia above the line y otros elementos como folletos, catálogos, promociones, etc. como estrategia below the line. Aunque también está entrando últimamente en los spots publicitarios como parte del Diseño Audiovisual.

\section{- Aplicación en diversas áreas}

La Publicidad no es el único campo. La Retórica interviene desde su origen en el Derecho y la Política. Y posteriormente en la Literatura y la Poesía para la generación de textos. Aristóteles ya intuyó su aplicación en diversos campos. Por su capacidad argumentativa y comunicativa, puede ser útil en muchas otras como por ejemplo en la Administración y Dirección de Empresas para las presentaciones de proyectos ante un público que debe tomar decisiones importantes. En el ámbito científico, la Retórica puede ayudar a explicar fenómenos complejos a través de metáforas, comparaciones, analogías, etc.

Ante la necesidad de toda organización de comunicar, ya sea pública o privada, el Diseño Gráfico tiene una presencia en la esfera social y económica. La flexibilidad de los modelos de creación característicos del Diseño están siendo actualmente aplicados en la gestión de compañías. Su capacidad para organizar la información hace que esté presente en todos los medios de comunicación ya sean escritos o audiovisuales. Además, por su capacidad sintética es de gran utilidad en la visualización de datos teniendo una aplicación directa no sólo en las empresas, sino también en las Ciencias 
para la explicación gráfica y sencilla de fenómenos complicados de explicar.

\section{- Carácter comunicativo}

Otro punto de unión entre el Diseño Gráfico y la Retórica es la Comunicación. La exteriorización de sus productos tiene un profundo carácter comunicativo.

La Oratoria o el arte de hablar en público ha sido muchas veces utilizada como sinónimo de Retórica. Aunque ésta puede actuar desde el lenguaje oral y es así como nació, también actúa construyendo el lenguaje escrito de las obras literarias, el lenguaje visual de la fotografía, la ilustración, el diseño gráfico y el lenguaje audiovisual de películas y anuncios.

Del mismo modo, el Diseño Gráfico se ha convertido en sinónimo de Comunicación Visual interviniendo en la creación de todos sus mensajes. La principal finalidad de todas las piezas gráficas, independientemente de las especialidades en las que han sido creadas (editorial, publicitaria, identidad corporativa), es la Comunicación. También los productos que son resultados del Diseño Objetual tienen un profundo carácter comunicativo porque los objetos hablan y transmiten mensajes más allá de su uso.

\section{- Carácter persuasivo}

Todo acto comunicativo tiene una intención persuasiva. Ambas disciplinas tienen entre sus objetivos el intento de convencer a un público. En ocasiones este objetivo, puede ser tergiversado convirtiéndose en manipulación.

En la Retórica es la base fundamental. Desde la tradición aristotélica, se considera que un discurso es persuasivo si convence al público con razonamientos o argumentos que apelan a la lógica, la ética y la emoción. La convicción no está completa si sólo se disfraza el mensaje de un contenido estético. En el sentido de la cultura helénica, lo bello es también bueno y justo.

En el Diseño Gráfico ocurre algo parecido. A veces, el público general cree que su función es "poner bonito" el mensaje. Las piezas gráficas tienen entre sus objetivos convencer a un público determinado para que realice una acción, pero ésta no es siempre comprar o consumir, también es informar, mostrar, educar, orientar...

\section{- Carácter intelectual}

Como consecuencia de su carácter procesual y metodológico, también se puede afirmar que se trata de disciplinas de una marcada intelectualidad. La herramienta de un retórico, de un diseñador o de un creativo es el pensamiento. Los tres planifican y prevén como va a ser un discurso, un diseño o una idea y cómo va a ser su aplicación sin estar aún elaborados. Son propios de ellos el pensamiento divergente y el pensamiento productivo.

- Carácter didáctico

La Retórica ha tenido una tradición con raigambre en la Escolástica medieval. Era una 
de las asignaturas que componían la educación que debía tener toda persona basada en las siete artes liberales, divididas en dos grupos de estudio: el trivium que comprendía la Gramática, la Retórica y la Dialéctica y el cuadrivium que englobaba la Aritmética, la Geometría, la Astronomía y la Música.

El Diseño Gráfico muestra y demuestra la información que nos enseña a través de sus piezas y las imágenes que utiliza. Costa y Moles (1991, p. 57) hablan de una imagen didáctica o de grafismo didáctico que se esfuerza en hacer compresibles y aprehensibles las cosas que son complejas o abstractas, las cosas ocultas e impenetrables por nuestros sentidos, los procesos temporales que no podemos imaginar de una sola vez, los fenómenos de lo infinitamente grande y lo infinitamente pequeño.

\section{- Carácter estético}

En ocasiones se produce una confusión entre el Arte y la Estética. Ésta se dedica al estudio de la esencia y la percepción de la belleza. Las dos disciplinas dan lugar a productos estéticos y, en ocasiones, también artísticos. La Retórica busca la belleza en la palabra y da como resultado obras literarias y poéticas. El Diseño Gráfico se aleja del Arte, pero inevitablemente sus piezas son estéticas. Usa en muchas ocasiones recursos artísticos como el dibujo o la ilustración para buscar en sus mensajes una recepción que llame la atención. La función estética debe estar acorde con los objetivos de la comunicación y no primar sobre los demás.

\section{- Carácter heurístico}

La Heurística es el arte del descubrimiento. Procedente del griego cupıoketv significa descubrir, hallar, encontrar... Se la identifica con la estrategia o los métodos para hacer más sencilla la solución de problemas complejos. En ocasiones suele ser utilizada como sinónimo de Creatividad. También la fase de la inventio retórica recibe el nombre

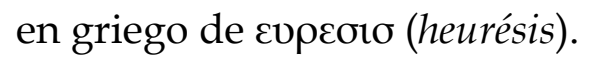

La Retórica y el Diseño Gráfico tienen un carácter indeterminado en el sentido de que no se sabe a ciencia cierta el resultado que se va a obtener. Por eso las ideas que generan se basan en el descubrimiento y después en su evaluación.

\section{- Carácter humanístico}

El ser humano es el eje central de las dos disciplinas. La Retórica tiene un profundo sentido democrático basado en que su intervención sólo es posible cuando hay dos opiniones enfrentadas para las que se busca un acuerdo. Su esplendor en la Antigüedad griega y romana también fundamentó una buena parte del pensamiento occidental.

El objetivo principal del Diseño es mejorar la calidad de vida del ser humano, resolver sus problemas más cotidianos. Es el configurador del entorno artificial que le rodea, aunque muchas veces, éste se vuelve en su contra. 


\section{TRASPOSICIÓN DEL PROCESO DE CREACIÓN DEL DISCURSO RETÓRICO AL DISEÑO GRÁFICO}

Diseñar es una forma de escribir, de narrar y de crear discursos. Para Albert Isern (1984, pp. 50-55), el Diseño Gráfico es una especie de gramática de las imágenes y de las palabras con reglas, sintaxis y ortografías específicas que nos remiten a formas, cromatismos y composiciones...

...en una apasionante arte de la combinatoria. Su privilegiada conformación como lenguaje dual en su simultánea expresión (icónica y verbal) posibilitan unas propuestas de comunicación ricas en registros que el profesional del Diseño debe utilizar con ingenio y sensibilidad para llegar unívocamente al perfil del grupo objetivo al que se dirige.

La capacidad narrativa es, pues, inherente en los productos del Diseño Gráfico como discursos visuales que son. En los discursos creados por el diseñador gráfico es importante el "qué" se dice (inventio) y el "cómo" (elocutio) se dice. La emisión de estos mensajes debe ser controlada e intencionada para evitar interpretaciones incorrectas. La disposición de los elementos gráficos en la retícula nos ayuda a decidir el "dónde" (dispositio) dentro del espacio del soporte en función del mensaje y su forma.

De la correspondencia entre la intención comunicativa por parte del diseñador y la captación de ese mensaje por parte del usuario final depende en gran medida la forma en que se presenta el discurso gráfico. A la comprensión del mensaje hay que añadir una dificultad más previa a la recepción: la captación y el mantenimiento de la atención del receptor. Es necesario guiar sus ojos a través de un recorrido narrativovisual establecido por una retícula bien construida que evite que el receptor se salga de él y se produzca una interrupción del mensaje y, por tanto, del significado a transmitir. Ante el bombardeo constante de información al que estamos sometidos se hace necesaria la figura del diseñador no sólo como comunicador visual sino como organizador y articulador que dote a los usuarios de los recursos visuales para que naveguen por el inmenso océano que supone la gran cantidad de textos e imágenes que son emitidos en la sociedad actual.

Veamos cómo un diseñador se plantea la creación de un discurso gráfico siguiendo pautas paralelas a las de un orador clásico. Nos vamos a centrar en las fases denominadas constituyentes del discurso, inventio, dispositio y elocutio, las tres primeras, consideradas así por ser las etapas creativas por excelencia ya que las otras dos, memoria y actio, se realizan una vez creado el discurso. Hay que tener en cuenta que son fases creativas del discurso reversibles e íntimamente relacionadas. Su interrelación hace que una no pueda existir sin las otras dos y a menudo se suceden de manera simultánea.

\subsection{Inventio - Conceptualización}

El diseñador gráfico comienza su discurso determinando el "qué" decir, al igual que el 
orador en la inventio, buscando los argumentos necesarios para lograr la adhesión del público al que se va a dirigir. Estos argumentos se materializan en una doble naturaleza: textual y visual. La primera, apela a la lógica debido a la enorme capacidad de producción de pensamiento que tiene la palabra (logocentrismo de la cultura tradicional) y la segunda, apela a la emoción por la influencia sensorial, sugestiva y motivadora que posee la imagen (imagocentrismo de la cultura contemporánea).

Los oradores buscaban sus argumentos partiendo de los tópicos o lugares comunes $(\square \square \square \square \square$ o loci), es decir, conceptos generales aceptados y reconocidos por el público al que se dirige el discurso. Los diseñadores también parten de tópicos que después son transformados para potenciar su creatividad y expresión de una forma más llamativa e impactante buscando la persuasión del público. De forma inicial se fija el tema y se orienta hacia el mensaje para posteriormente buscar la manera de expresarlo de una manera más creativa y original en la elocutio.

En esta etapa también se empiezan a seleccionar los elementos gráficos que mejor expresen y representen los argumentos. Comienzan a realizarse las primeras aproximaciones a modo de boceto. Estos elementos irán perfilándose, variando y transformándose a lo largo del proceso.

\subsection{Dispositio - Composición}

Una vez determinados los argumentos más adecuados, el diseñador debe tomar la decisión de "dónde" colocarlos para reforzar su eficacia persuasiva. La selección del material textual y visual realizada en el inventio se ha hecho en función de su posible uso, ordenación y efecto.

En esta etapa, el diseñador establece la estructura general de su discurso gráfico. Por lo tanto tiene que tomar la decisión de cuál es el soporte más adecuado para transmitir el mensaje $y$, según sea éste, decidir su formato o tamaño con arreglo a limitaciones técnicas e incluso económicas. Tras estas decisiones, se procede a la construcción de la estructura reticular en función de los elementos gráficos con los que cuenta y el orden en el que se quieran disponer.

Aunque pueda parecer paradójico, el elemento del Diseño Gráfico con más poder organizativo, estructurante y jerárquico es el contragrafismo o el blanco, a pesar de su ausencia de materialidad. Gracias a los blancos, el diseñador puede canalizar de forma controlada la mirada del receptor, establecer su recorrido visual y le permite crear divisiones entre las diversas partes del discurso gráfico que le confieren el orden y la jerarquía necesarios para lograr su correcta compresión y, por tanto, la eficacia comunicativa.

La retícula y el orden que establece en el discurso gráfico tienen una función pragmática de vital importancia para que el mensaje logre la intención deseada. Su intermediación permite poner en contacto al emisor con el receptor a través del mensaje. Algunos productos gráficos (como un libro, una publicación periódica o una 
página web) disponen de un tiempo de recepción más prolongado. La necesidad de impacto es importante, pero no menos que mantener la capacidad de atención en el receptor. El diseñador debe facilitar en estos casos la prolongación del interés mediante el orden y la claridad en la exposición de los argumentos. La proporción entre imagen y texto puede estar igualada o bien decantarse más por el segundo.

Debido al carácter efímero de la recepción de otras piezas gráficas (como carteles o anuncios) y ante la desbordante presencia de numerosos productos dentro del mismo contexto social, éstas deben buscar el impacto inmediato en el receptor como una necesidad urgente y prioritaria. Dichas piezas apuntan directamente a la emoción y deben ser breves y concisas por lo que suele predominar la imagen sobre el texto.

Según sea el discurso, los objetivos, el soporte, el formato y el público objetivo podemos optar por diversos tipos de retículas o estructuras compositivas.

La estructura compositiva implica también un orden narrativo de los argumentos dentro de retícula. Los dos tipos de órdenes generales son el orden natural, adecuado para discursos lógicos y raciones, y orden artificial, para discursos emotivos y persuasivos. La Retórica Clásica establece la división de las partes del discurso que se pueden trasladar también al discurso visual y que son muy utilizadas en los mensajes publicitarios:

- Exordio: corresponde al comienzo. La primera impresión es muy importante y el diseñador gráfico debe reclamar la atención para que el receptor inicie el discurso. Por eso suele emplearse una imagen o un titular impactante. A partir de ahí, el diseñador debe mantener su interés para que complete el recorrido visual completo.

- Narración: es la exposición de los hechos. Se emplea para contar presentar un producto o servicio de manera textual y/o visual. Si representa sólo de manera textual sería como el cuerpo de texto de un anuncio.

- Argumentación: se trata del núcleo central del discurso. En ella se presentan los beneficios y las propiedades del producto o servicio. Se puede utilizar texto e imagen, bien por separado, bien en combinación.

- Epílogo: conclusión o resumen. Textualmente se puede reproducir en un claim y visualmente en el logotipo de la marca anunciante.

Esta división se puede condensar, según las necesidades técnicas y espacio-temporales y según el grado de impacto que se quiera causar, suprimiendo el exordio (división tripartita como el clásico orden narrativo de planteamiento, nudo y desenlace) o eliminando el principio y el final. En esta fase, el discurso aún no tiene su aspecto final que se pulirá mediante una iteración constante de las tres etapas.

\subsection{Elocutio - Expresión}

En esta fase el diseñador establece el aspecto y la expresión formal de todos los elementos que constituyen el discurso gráfico dentro de una primera disposición 
elaborada en el formato y la retícula. Es el momento de darle forma a los argumentos siguiendo las guías establecidas, de rellenar la retícula y darle cuerpo a la estructura compositiva.

Para ello el diseñador tendrá que tomar decisiones relativas a una microdisposición dentro de la retícula que potenciarán el poder persuasivo de su discurso visual:

- Texto: desde un punto de vista estético, debe decidir cuál es la tipografía que mejor representa o armoniza con el argumento creativo y, desde el punto de vista funcional, cuál es el tipo de letra, su cuerpo, interlineado y alineación más adecuados para su legibilidad. Se pueden establecer niveles de jerarquización eligiendo dos tipografías distintas utilizadas con diferentes funciones (titular o cuerpo de texto) que rompan la monotonía del texto.

- Color: no sólo es un elemento de gran poder persuasivo. La elección de una gama cromática adecuada permite destacar ciertas partes de nuestro discurso mediante fondos o establecer sistemas de identificación y navegación dentro de él.

- Formas e imágenes: puede tratarse de dibujos, ilustraciones, infografías o fotografías que estén relacionadas con el argumento de nuestro discurso visual. Aunque su colocación ha estado prevista en la anterior etapa, pueden sufrir modificaciones en su tamaño o encuadre.

Una vez colocados todos los elementos gráficos dentro de la retícula, éstos se pueden modificar mediante figuras retórico-visuales basadas en simples operaciones como la adjunción, supresión, permutación y sustitución con la finalidad de aumentar su valor estético y persuasivo. Su finalidad es doble. Por un lado constructiva, creando ritmo y estructura en la composición de la pieza, y por otro, creativa, alterando total y/o parcialmente los elementos puestos en juego en el diseño para lograr una nueva expresión que llame más la atención en el receptor del mensaje. 


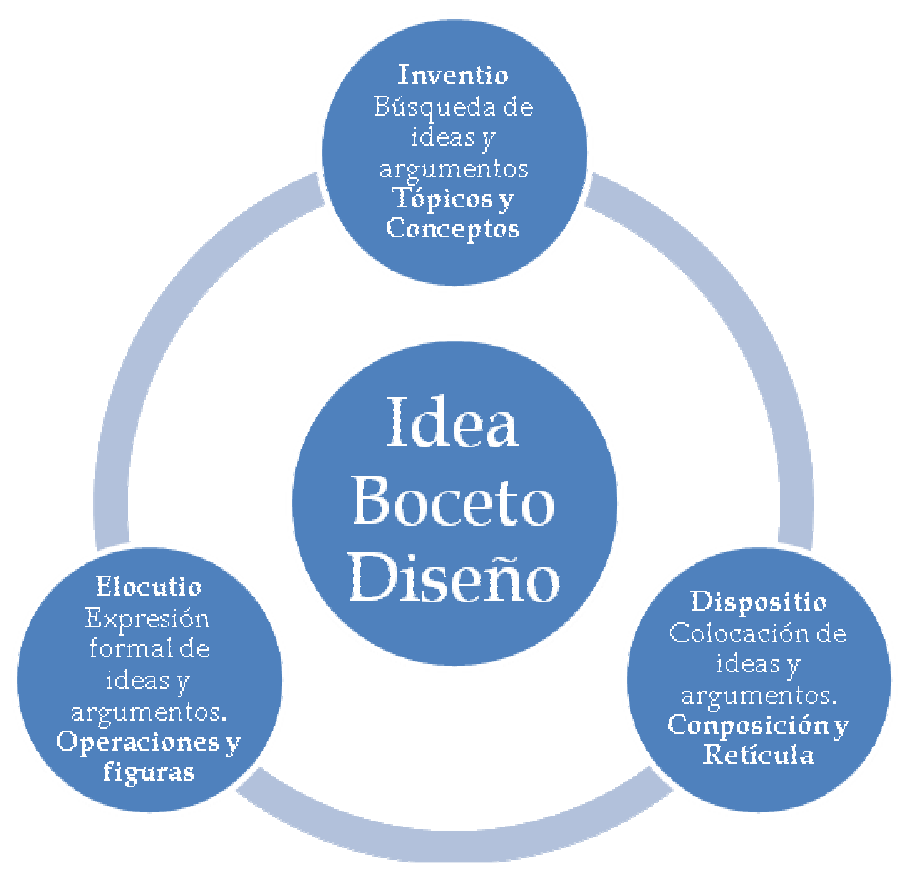

Figura 1. Esquema del proceso creativo del Diseño Gráfico basado en la Retórica. Fuente: Elaboración propia.

\section{EL BOCETO: LA MATERIALIZACIÓN DE LAS IDEAS}

La realización de bocetos para expresar de forma gráfica las ideas y conceptos supone la primera aproximación al desarrollo del argumento gráfico en el que se ponen en común la inventio, la dispositio y la elocutio, aunque de manera provisional. Supone un primer tanteo de la idea y una representación de modo esquemático e inacabado (ya que muchas veces no incluye todavía el color o la tipografía, además de sufrir variaciones en su desarrollo final), dejando ver la potencialidad de ese argumento para ser expresado en el lenguaje visual. Es la idea en bruto que luego hay que pulir y perfeccionar en la dispositio para la creación de una estructura compositiva y en la elocutio para trabajar su expresión final. Generalmente se realizan varios para aproximarse al objetivo del diseño, pero finalmente se seleccionará sólo uno (el que cumpla los requisitos establecidos y valorados por el diseñador) para ser completado y ejecutado hasta el final.

Un boceto no sólo se compone de signos visuales, sino que también incluye los signos lingüísticos que expresan de forma resumida los conceptos con palabras. Es muy habitual que se establezca un breve listado de conceptos claves que se escriben al margen. Alrededor de ellos se comienzan a generar las primeras traslaciones del lenguaje escrito al lenguaje visual para las cuales hay que seleccionar los signos visuales más adecuados para la expresión formal de dicha idea.

También en los bocetos se empiezan a vislumbrar las primeras pruebas de cómo los elementos gráficos deben colocarse en el espacio para cumplir mejor su función 
comunicativa. Del mismo modo, nos dejan entrever el acercamiento a una resolución estilística del concepto a expresar.

\subsection{Análisis de los diseños de Manuel Estrada}

Para poder mostrar esta comparación entre la idea en bruto y el resultado final vamos a analizar brevemente la conversión de la idea en un diseño definitivo a través de una exposición del diseñador gráfico Manuel Estrada titulada "Donde nacen las ideas. Cuadernos del equilibrista" y que se inauguró el 11 de junio de 2010 en el Centro Atlántico de Arte Moderno de Las Palmas de Gran Canaria. Estrada, uno de los exponentes principales del Diseño Gráfico español actual, describe su proceso creativo inicial a través de bosquejos, esquemas y apuntes realizados a mano en cincuenta cuadernos. En ellos destaca la importancia de las ideas en el Diseño y su visión se acerca mucho a los principios retóricos de la inventio como búsqueda constante para hallar el argumento (Estrada, 2010): “Las ideas no nacen del cielo. Son fruto de la permanente búsqueda que es el trabajo del diseñador". Estrada describe su trabajo como un reflejo de la búsqueda y de sus hallazgos, más o menos acertados, que posteriormente se convertirán en cubiertas de libros, revistas, carteles o logotipos.

Estos cuadernos no sólo están llenos de dibujos, sino también de pensamientos escritos, de conceptos abstractos que adquieren formas inusuales acordes con el encargo. Cumplen para el diseñador tres funciones: diario o agenda donde se marcan las tareas y faenas cotidianas de cada día, archivo documental del proceso, muy útil a la hora de exponer y presentar sus trabajos al cliente $y$, finalmente, una herramienta para su proceso de Diseño.

Como podemos observar en algunos de los trabajos mostrados, la idea principal emerge en el papel a través de trazos irregulares, rápidos e inacabados y con un tratamiento del color muy básico. La tipografía está expresada mediante la caligrafía personal del autor. Todo esto pasará posteriormente a ser refinado y pulido por los integrantes del estudio de Manuel Estrada a través del ordenador con la ayuda de software informático. Vemos cómo el boceto inicial de la cubierta para el libro "Quo vadis" se transforma en un bodegón fotográfico creado ex profeso para diseñar la imagen que abrirá la novela al más puro estilo de Daniel Gil y sus cubiertas para la colección de bolsillo de Alianza Editorial o cómo el signo identificativo de don Quijote es creado con perfección geométrica a partir de un círculo rojo. Pero en algunos casos, ese aspecto inacabado (que es propio del boceto) se respeta en el diseño final con técnicas básicas como collage. El diseñador emplea las tijeras como si fuera un lápiz.

Es interesante resaltar cómo los argumentos ya son expresados con figuras retóricas para reflejar su potencialidad creativa. Por ejemplo, una personificación en la cubierta de la novela "El tulipán negro", un símbolo del Cristianismo a través de la construcción de un pez en orientación vertical que es atravesado por un trazo de gran grosor de color rojo para destilar la esencia de "Quo Vadis" o la sinécdoque a través de la utilización de una bacía de barbero como una parte característica que representa el concepto global del famoso caballero andante don Quijote... 
También el autor ya va remarcando con sus bocetos la posición en el formato que deben ocupar cada uno de los elementos y dónde se van a colocar los títulos y otros textos auxiliares, que finalmente adquirirán la forma de una tipografía concreta.

El resultado es una imagen sintética compuesta por pocos elementos gráficos, pero con una enorme carga semántica que destila la esencia de la obra. Estos elementos sufren diversas modificaciones hasta llegar al resultado final y estas alteraciones se corresponden con las operaciones retóricas de adición, supresión, sustitución y permutación que dan como resultado la creación de figuras retóricas que potencia su expresividad, llegando a convertirse en auténticos poemas visuales. Detrás de esas imágenes aparentemente sencillas se aprecia un discurso de gran profundidad. Lo que demuestra que diseñar es una actividad intelectual que se materializa en un lenguaje visual.
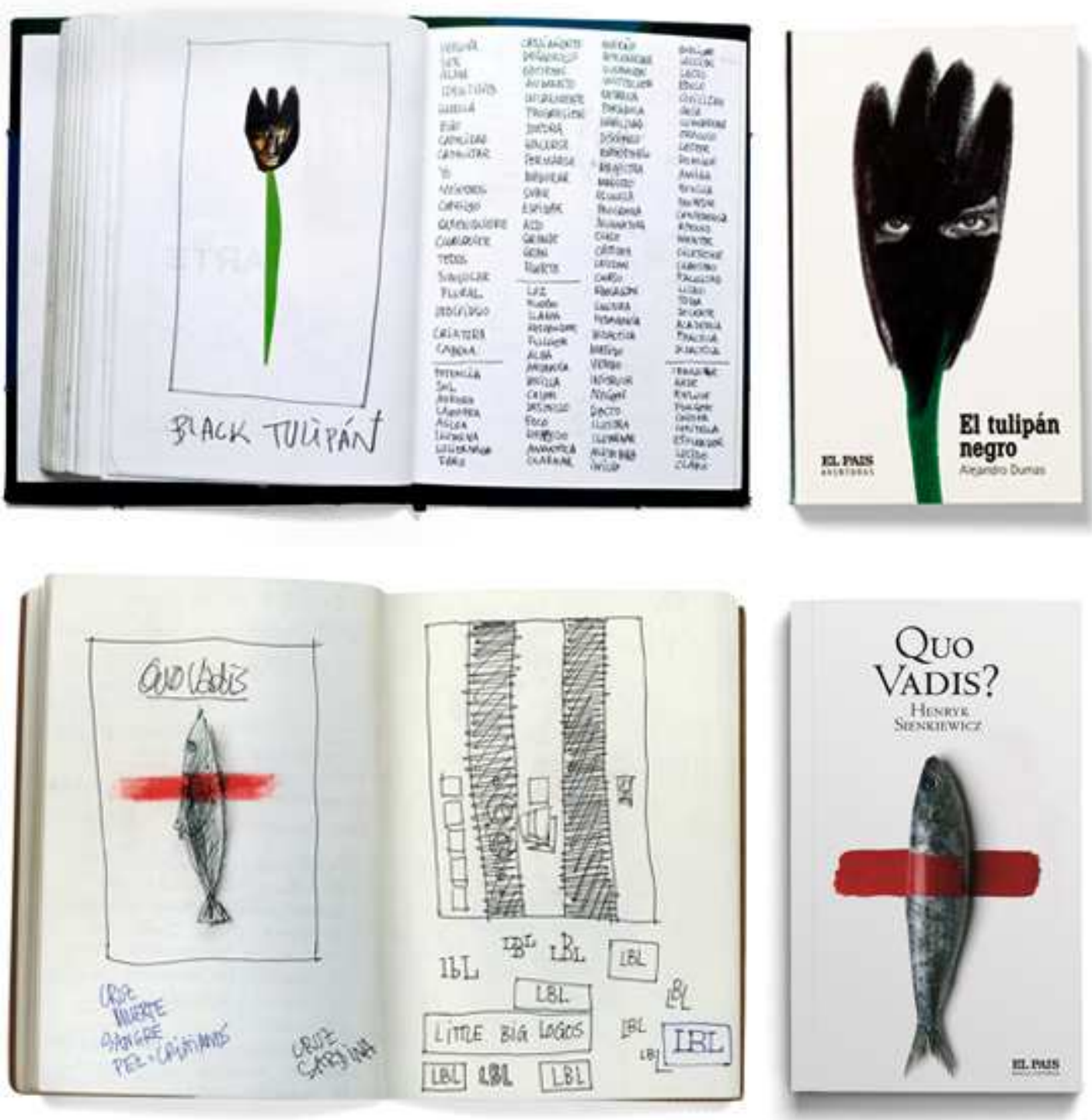

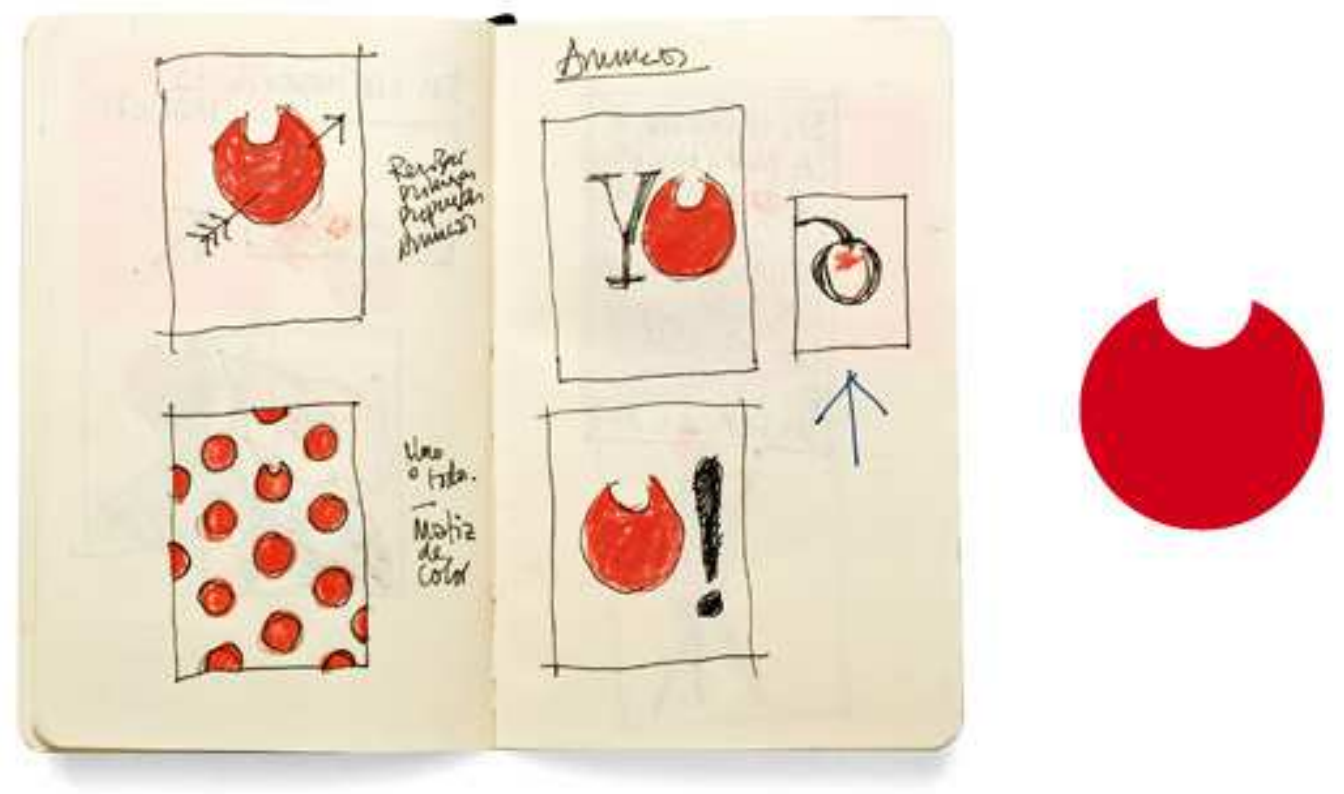

Figura 2. Muestra de bocetos realizados por Manuel Estrada y a su derecha el resultado final. Fuente: manuelestrada.com.

\section{CONCLUSIÓN}

Retórica y Diseño Gráfico comparten objetivos y procesos creativos. Se complementan mutuamente para materializar ideas y conceptos con un origen textual en imágenes de un alto contenido discursivo. La gestación de un discurso se puede comparar con la gestación de un diseño gráfico.

La aplicación del proceso creativo de la Retórica abre la posibilidad de una nueva metodología en el Diseño Gráfico que es flexible y que incide más que en las competencias artísticas del diseñador en las competencias comunicativas y persuasivas propias del orador. Hemos podido comprobar de forma abierta y transparente en los ejemplos de Manuel Estrada cómo su proceso creativo es claro y perfectamente entendible desde la perspectiva de la Retórica en la que los diseños se convierten en discursos visuales.

Abrir la "caja negra" de lo que ocurre en el proceso nos ayuda a comprender y valorar mejor el resultado, además de desterrar el mito de la genialidad artística. Conocer el camino que va de la idea al diseño nos demuestra que el resultado es fruto de una toma de decisiones de carácter tanto racional como emotivo, una criba y selección en busca del resultado óptimo, que nunca responde a caprichos personalistas.

\section{BIBLIOGRAFÍA}

Aristóteles, 2002: Retórica. Alianza Editorial. Madrid. 
Barthes, Roland (1986): “Retórica de la imagen" en Lo obvio y lo obtuso. Imágenes, gestos, voces (pp.29-47). Ediciones Paidós. Barcelona.

Costa, Joan y Moles, Abraham (1991): Imagen Didáctica. Ediciones CEAC. Barcelona.

Durand, Jacques (1972): “Retórica e Imagen publicitaria” en METZ, C. et alt.: Análisis de las imágenes, (pp.81-112). Tiempo Contemporáneo. Buenos Aires.

Estrada, Manuel (2010): “Exposición De donde nacen las ideas. Cuadernos del equilibrista" [en línea]. En Manuel Estrada Design. Recuperado el 10 diciembre de 2010 http:// manuelestrada.com/team?s=0-1\&id=371

Grupo $\square$ (1993): Tratado del signo visual. Cátedra. Madrid.

(1987): Retórica General. Paidós. Barcelona.

Isern, Albert (1984): “El diseño que pudo haber sido" en revista De Diseño no5, pp. 5055 .

Lakoff, George y Johnson, Mark (1991): Metáforas de la vida cotidiana. Cátedra. Madrid.

Lausberg, Heinrich (1983): Manual de Retórica Literaria. 3 vol. Editorial Gredos. Madrid.

Perelman, Chaim. y Olbrechts-Tyteca, Lucie (1989): Tratado de la argumentación. Editorial Gredos. Madrid.

\section{Roberto Gamonal Arroyo}

Doctor en Creatividad Aplicada por la facultad de Bellas Artes UCM y licenciado en Periodismo por la Facultad de Ciencias de la Información UCM. Diseñador gráfico profesional e investigador en temas relacionados con el Diseño, la Comunicación Visual y la Retórica. Profesor Asociado en la facultad de Ciencias de la Información. Colabora con el Istituto Europeo di Design dando clases de Historia del Diseño e Historia de la Gráfica en sus cursos trienales. En esta misma institución educativa codirige el Curso de Especialización en Diseño de Tipografía y el Máster de Diseño Editorial: medios impresos y digitales. 